\title{
Fine Structure of Atrial Natriuretic Peptide (ANP)-granules in the Atrial Cardiocytes of the Mouse, Rat and Mongolian Gerbil
}

\author{
Hiroharu MIFUNE, Syusaku SUZUKI*, Yasutaka NODA, \\ Shiro MOHRI**, and Koshi MOCHIZUKI*** \\ Institute of Animal Experiment, Kurume University School of Medicine, 67 Asahi-machi, \\ Kurume-shi, Fukuoka 830, *Institute of Experimental Animals, Shimane Medical \\ University, 89-1 Enya-cho, Izumo-shi, Shimane 693, ** Institute for Animal \\ Experiment, Faculty of Medcine, Kyushu University, 3-1-1 Maidashi, \\ Fukuoka-shi, Fukuoka 812, and ${ }^{* * *}$ Laboratory of Biomedical Science, \\ College of Agriculture \& Veterinary Medicine, Nihon University, \\ 1866 Kameino, Fuzisawa-shi, Kanagawa 252, Japan
}

(Received 3 August 1990/Accepted 16 November 1990)

\begin{abstract}
Mouse, rat and Mongolian gerbil atrial and ventricular cardiocytes were examined by immunohistochemistry, and the right atrium including the auricle was examined by transmission electron microscopy. In addition the ANP granules of both right atrial and auricular cardiocytes were analyzed by ultrastructural morphometry. ANP immunoreactivity was detected in the atria of all three species, and the most intensely reacting cardiocytes were localized in the right auricular part of the atrium. These reactions were more prominent in the mouse and rat than in the Mongolian gerbil. ANP immunoreactivity was not detected in the ventricular myocardium of any of the three species, but was occasionally seen in the subendocardium of the ventricular septum. Ultrastructurally, the ANP granules in the auricular and atrial cardiocytes were observed to be variable in size and number, and these granules were located principally in the paranuclear region in association with the Golgi apparatus, and found throughout the sarcoplasmic layers in all three species. The ANP granules were classified into two types; A-granules containing a conspicuous electron-dense core possessing a membrane, and Bgranules having profiles with a fibrillogranular, less electron-dense core than the A-granules and an indistinct membrane. The features of these granules were similar in all three species. When examined by ultrastructural morphometry, the number of each type granule and the total number of granules in the right auricular and atrial cardiocytes of the mouse and rat were significantly greater than in the Mongolian gerbil. The total number of granules in the right auricular cardiocytes was significantly greater than in the cardiocytes of the right atrium exclusive of the auricle, however, there was no significant difference between the number of $\mathrm{A}^{-}$ granules and B-granules in the three species. The diameter of each type of granule in the right auricular and atrial cardiocytes of the mouse and rat was significantly greater than in the Mongolian gerbil, and the diameter of the A-granules was significantly greater than the diameter of the $\mathrm{B}^{-}$granules in all three species.
\end{abstract}

The presence of a particular type of granule population in atrial cardiocytes was discovered by Kisch [15]. Palade [21], and Jamieson and Palade [13] described these secretory-like granules in a number of mammalian species, including man, and postulated that they were formed in the Golgi apparatus of atrial cardiocytes. These granules were assumed to be the storage sites of specific peptides [7], and De Bold [8] reported that extracts of this granule- rich fraction had natriuretic properties. Recently, Kangawa and Matsuo [14] isolated new peptides from the human heart and named them atrial natriuretic polypeptides (ANPS).

Cells containing these granules were referred to as "myoendocrine cells" to distinguish them from other cell types in the heart, and these myoendocrine cells were found in great numbers in the right and left auricle $[10,19]$. On the basis of their ultrastructural appeara- 
nce, the ANP granules in the cardiocytes are generally classified into two [11] or three types $[2,5]$. There has been very little comment in the literature on the functional significance of granules having different ultrastructural appearance. It has been suggested, on the other hand, that they may represent stages of granule maturation $[20,27]$, however, there is no evidence to suggest that any particular sequence is associated with a particular granule type.

Ultrastructural studies of myoendocrine cells in the heart of various mammalian species $[5,6,13,25]$ have been reported, however, to the best our knowledge, no detailed immunohistochemical or ultrastractural studies of such cells in the Mongolian gerbil, mouse or rat have been published. In the present study, the structure of the myoendocrine cells of the mouse, rat and Mongolian gerbil were examined by means of immunohistochemistry and transmission electron microscopy (TEM). Structural and distribution differences in the ANP granules were investigated in these three species. There have been only a few reports concerning the number and diameter of such granules in atrial cardiocytes using morphometric methods $[5,11,24]$, and these reports have not described variations in the number and diameter of ANP granules in the atrial cadiocytes of various animal species, so in this paper we analyzed differences in the number and diameter of ANP granules in the right auricular and atrial cardiocytes of these three species using morphometric methods.

\section{Materials and Methods}

Hearts of 5 male 90-day-old laboratory animals each (Jcl : ICR mice; Jcl : Wistar rats ; CLEA Japan, Inc., Sea : Mongolian gerbils ; Seiwa Experimental Animals, Ltd.) were used in this study. These animals were housed in an environmentally air-conditioned room (temperature : $24 \pm 1{ }^{\circ} \mathrm{C}$; humidity : $55 \pm 5 \%$; automatic lighting : 7:00 a. m. to $7: 00$ p. m.). They were provided with a pellet diet CE-2 (CLEA Japan, Inc. Osaka, Japan) and water ad libitum. Atrial and ventricular tissues were removed from these animals under Nembutal anesthesia.

For electron microscopic examination, tissue from the right auricle and atrium (central portion of atrium excluding the auricle) were fixed in $2 \%$ paraformaldehyde $-2.5 \%$ glutaraldehyde in $0.1 \mathrm{M}$ cacodylate buffer at $\mathrm{pH}$ 7.4 and post-fixed in $1 \%$ osmium tetroxide in the same buffer. The specimens were dehydrated in a graded series of ethanol and embedded in Epon 812. Thin sections were double-stained with uranyl acetate and lead citrate and examined with a JEM-2000 EX electron microscope.

For immunohistochemical examination, atrial and ventricular tissue blocks were fixed with Zamboni's solution for $24 \mathrm{hrs}$ at room temperature. After washing with $0.15 \mathrm{M}$ PBS at $\mathrm{pH} 7.3$, the samples were dehydrated, embedded in paraffin and cut into $5 \mu \mathrm{m}$ sections. After removing the paraffin, the sections were washed with $\mathrm{PBS}$, treated with $3 \% \mathrm{H}_{2} \mathrm{O}_{2}$ in methanol for $20 \mathrm{~min}$, then incubated with $1 \%$ normal rabbit serum for $20 \mathrm{~min}$ at room temperature. They were incubated with primary antibody overnight at room temperature. The antibody used was rabbit antiserum against atrial natriuretic peptide(human, 1-28) [Peptide Labs, Japan], diluted $1: 100$ to $1: 500$ with PBS containing $0.02 \%$ Triton X 100 . Further incubation was performed with swine anti-rabbit immunoglobulin (1:40; DAKO, Denmark) and then with PAP complex $(1: 40$; DAKO, Denmark) for $20 \mathrm{~min}$ at room temperature. After each step, sections were rinsed thoroughly in PBS. Staining for peroxidase was performed using $4 \%$ diaminobenzidine and $0.004 \% \mathrm{H}_{2} \mathrm{O}_{2}$ in Tris- $\mathrm{HCl}$ buffer ( $\mathrm{pH} \mathrm{7.6)}$ for $10 \mathrm{~min}$. As controls for the immunostaining, sections from the same blocks were treated with normal rabbit serum instead of primary antibody.

In the case of ultrastructural morphometry, the number and diameter of ANP granules in right atrial and auricular cardiocytes were measured by the modified morphometry method of Cantin et al. [5]. Thin sections were viewed on a JEM-2000 EX electron microoscope at a magnificaion of $\times 3000$. Fifteen photographs were randomly chosen from sections of the right atrial and auricular cardiocytes of each animals in accordance with the criteria proposed by Cantin et al. [5]. The counting and measurement of ANP granules was done on $25 \mathrm{~cm} \times 30 \mathrm{~cm}$ prints at a final magnification of $\times 14,000$, corresponding to an area of 382.7 $\mu \mathrm{m}^{2}$. The means ( $\pm \mathrm{SD}$ ) of counts were calculated for 45 photographs from 3 animals of each species, and measurements were made 
of at least 200 granules from each species.

\section{Results}

Immunohistochemistry : ANP immunoreactivity was detected in the cytoplasm of the cardiocytes of both the right and left atria in all three species. Reactivity was more prominent in the right atrium (Figs. 1,2). In all three species, the ANP reaction deposits were strongly demonstrated in the perinuclear regions of cardiocytes in the auricular part of the atrium (Figs. 3,4 ). The most intensely reacting cardiocytes were localized in the right auricular part of the atrium of the mouse, rat and Mongolian gerbil. The reaction was more prominent in the mouse and rat than in the Mongolian gerbil (Figs. 3, 5, 6) . In many sections, the subpericardial cardiocytes in all regions of the atria were more reactive than those located in the deep atrial wall or in the subendocardial area of the various species (Fig. 7). No ANP immunoreactivity was detected in the ventricular myocadium of any of the three species, however, some was occasionally seen in the subendocardium of the ventricular septum (Figs. 8, 9).

Ultrastructure : In all three species, the atrial and auricular cardiocyes contained a central nucleus, numerous mitochondria, myo- fibrils, variable amounts of rough endoplasmic reticulum (RER), Golgi apparatus and electrondense granules (Figs. 10,11,12). The granule profiles were variable in size and number, and the granules were principally located in the paranuclear region in association with the Golgi apparatus. Most of the granules were found at the poles of the elongated nucleus (Fig. 11). The granules were observed throughout the sarcoplasmic layers intervening between myofibrilar bundles and, occasionally, under the plasma membrane near the Golgi apparatus. There were more granules in cardiocytes of the right auricle than of the right atrium in all three species (Figs. 10,13). In the Mongolian gerbil, there were fewer granules in the cardiocytes of the right auricle and atrium than in the mouse or rat (Figs. 10,11,12). In all three species, the granules were classified into two types : A-granules containing a conspicuous electron-dense core separated from the limiting membrane by a narrow electron-lucent halo, and B-granules having profiles with a fibrillogranular, less electron-dense core than the Agranules and indistinct membrane (Fig. 14). Both A-and B-granules were of similar size, and were seen in the same areas in all three species (Figs. 15, 16).

Ultrastructural morphometry : The number and diameter of the granules in the right

Table 1. Comparative number and diameter of ANP-granules in right auricular and non-auricular atrial cardiocytes

\begin{tabular}{|c|c|c|c|c|c|c|}
\hline \multicolumn{4}{|c|}{ Number $(\mathrm{ME} \pm \mathrm{SD})$} & \multicolumn{3}{|c|}{ Right atrium exclusive of the auricle } \\
\hline Species & Type A & Type B & Total & Type A & Type B & Total \\
\hline Mouse & $66.7 \pm 6.02$ & $60.0 \pm 5.62$ & $126.7 \pm 9.84^{* *}$ & $39.7 \pm 7.36$ & $32.9 \pm 6.05$ & $72.6 \pm 12.87$ \\
\hline Rat & $61.4 \pm 9.87$ & $56.1 \pm 9.76$ & $117.5 \pm 19.13^{* *}$ & $46.2 \pm 5.33$ & $41.0 \pm 5.96$ & $87.2 \pm 9.64$ \\
\hline M. gerbil & $35.3 \pm 5.06^{*}$ & $30.2 \pm 5.33^{*}$ & $66.5 \pm 9.59^{*}, * *$ & $25.5 \pm 5.42^{*}$ & $21.3 \pm 6.43^{* * *}$ & $46.8 \pm 11.62^{*}$ \\
\hline
\end{tabular}

\begin{tabular}{|c|c|c|c|c|}
\hline \multicolumn{5}{|c|}{ Diameter $(\mathrm{ME} \pm \mathrm{SD})(\mathrm{nm})$} \\
\hline \multirow[b]{2}{*}{ Species } & \multicolumn{2}{|c|}{ Right auricle } & \multicolumn{2}{|c|}{ Right atrium exclusive of the auricle } \\
\hline & Type A & Type B & Type A & Type B \\
\hline Mouse & $318.7 \pm 54.5^{* *}$ & $284.0 \pm 51.2$ & $309.6 \pm 37.9^{* *}$ & $276.0 \pm 42.6$ \\
\hline Rat & $317.2 \pm 67.6^{* *}$ & $288.5 \pm 53.1$ & $316.9 \pm 67.0^{* *}$ & $286.7 \pm 56.4$ \\
\hline M. gerbil & $282.5 \pm 58.9^{*}, * *$ & $251.1 \pm 46.5^{*}$ & $274.3 \pm 43.8^{*}, * *$ & $244.3 \pm 52.1^{*}$ \\
\hline
\end{tabular}


auricular and non-auricular atrial cardiocyte of the three species are shown in Table 1. The number of each type of granule and the total number of granules in the right auricular and atrial cardiocytes in the mouse and rat were significantly greater than in the Mongolian gerbil $(p<0.01)$, and no significant difference was observed between the mouse and rat. Furthermore, there was no significant difference between the number of A-granules and $\mathrm{B}$-granules in the auricular and atrial cardiocytes of any of the three species. The total number of granules in the right auricular cardiocytes was significantly greater than in the right non-auricular atrial cardiocytes of each species $(p<0.01)$. The diameter of both types of granule in the right auricular and atrial cardiocytes of the mouse and rat was significantly greater than in the Mongolian gerbil $(p<0.01)$, but the mouse and rat were similar in this respect. In the auricular and atrial cardiocytes of all three species, the mean diameter of the A-granules was significantly greater than that of the B-granules $(p<0.01)$. No significant difference was found in the size of the A-granules of the right auricular and atrial cardiocytes of the three species, nor was any significant difference found in the size of the B-granules in the right auricular and atrial cardiocytes.

\section{Discussion}

Several investigators have used immunohistochemical techniques to study the distribution of ANP and ANP-related peptides (cardiodilatin, atrial natriuretic factors, atriopeptin II) in mammalian hearts $[4,9,18,19,23]$. Chapeau et al. [6] investigated the localization of immunoreactive synthetic atrial natriuretic factor in the heart of various animal species. They reported that the most intensely reacting cardiocytes are located in the auricle and that the number of cells with dense granules is greater in the right atrium than in the left. In our own immunohistochemical study, the ANP immunoreactivity of the auricle and atrium of all three species was the same as in these earlier reports. There have been a few reports stating that such differences in ANP localization in the auricle and atrium are closely related to blood pressure $[16,17,22]$. There is also a report, however, that in spontaneously hyperte nsive rats [12] the distribution of ANP reacting cells in the auricle and atrium is the same as in the normal rat. Toshimori et al. [26] reported that ANPS-immunoreactive cells are also observed in the pulmonary vein, havingless of a functional role as myocytes. It seemsthat more ANP-reacting cells functioning more as endocrine cells are encountered in the auricle, and these cells function less as myocytes. However, wecannot cleary determine on the basis of differences in intensity of ANP immunoreactivity in the right and left atria that this is related to different functional significance.

There have been no reports of morphometric analyses of the number and diameter of ANP granules in right auricular and atrial cardiocytes comparing the mouse, rat and Mongolian gerbil. Cantin et al. [5] have reported the number of ANP granules in various mammals and commented that the number of ANP granules in the atrium decreases as animal body size increases. Though the body size of the Mongolian gerbil is smaller than that of the rat, and larger than that of the mouse, the total number of ANP granules was less than in either the rat or mouse in our morphometric analysis. We cannot relate the different numbers of ANP granules in either the auricle and atrium of these three mammalian species to different body size. It seems that these differences are caused by physiological factors other than body size, for example, heart rate, blood pressure, feeding habits, water intake, etc.

Bompiani et al. [3] commented that the majority of secretory granules in the heart seem to fall into two types with regard to size and ultrastructure. Later, Berger and Rona [2] categorized A-and B-granules using similar criteria. They described A-granules as containing an electron-dense core which was often retracted and distinct from the inner aspect of the investing membrane, and $\mathrm{B}$-granules as characterized by a pale, fibrillogranular core. In our own study, the profiles of the secretory granules in all three animal species agreed with their findings. There have been a few comments on the functional significance of such differences in ultrastructural appearance. In recent years it has been suggested that granules having different structures may represent stages of granule maturation $[20,27]$. Anderson et al. [1] concluded that the major storage form is con- 
sistently the 126 amino acid propolypeptide. Cantin et al. [4] and Chapeau et al. [6] reported that both sequences of the biologically active ANP-28 fragment and overlapping regions of the prohormone molecule are co-localized in ANP granules on the basis of immunocytochemical labeling using specific antisera. If structural differences in granules represent different stages of granule maturation, mature granules should be distributed in domains different from those of immature granules. For example, most of the immature granules should be located in the Golgi area. However, we have been unable to find any differences in the distribution of $\mathrm{A}$-and $\mathrm{B}$-granules. This suggests that the structural differences in A-and Bgranules do not represent different stages of granule maturation. Skepper and Navaratnam [24] have reported that the morphology of Aand B-granule profiles is interchangeable during the tilting maneuver using TEM and have stated that studies of serial sections have revealed that equatorial sections through a granule yield the typical morphology of $\mathrm{A}^{-}$ granule profiles while peripheral sections through the same granule yield B type morphology. If peripheral sections through A-granules yield B-granule morphology, A-granules must be significantly larger than $\mathrm{B}$-granules, and there should be no statistical difference in the number of $\mathrm{A}$-and $\mathrm{B}$-granules in any species. In our own study, the B-granules were significantly smaller than the A-granules in the auricular and atrial cardiocytes of all three species, and there was no significant difference in the number of granules. In this study, however, we failed to confirm whether the morphology of $\mathrm{A}$-and $\mathrm{B}$-granule profiles was interchangeable during the tilting maneuver, so it would be difficult to conclude that the morphological characteristics of both types of granules depend on the sectional planes in which they are viewed on the basis of our morphometric analysis alone.

In the present investigation, the size and number of ANP granules in the cardiocytes of the Mongolian gerbils were significantly different from those of the mouse and rat, however the same conclusion regarding a different function for these granules in the cardiocytes of these three specis could not be reached.

\section{References}

[ 1] Anderson, J., Christofides, N. D., Vinas, P., Polak, J. M., and Bloom, S. R. (1985). The localization, molecular forms and in vivo release of atrial natriuretic peptide immunoreactivity (ANP-IR) in the rat. Clin. Sci, Suppl, 15, 55.

[2] Berger, J. M. and Rona, G. (1971). Functional and fine structural heterogeneity of atrial cardiocytes. In Methods and achievements in experimental pathology, vol. 5, pp 540-590, Bajusz, E. and Jasmin, G. (eds.), S. Karger, Basel.

[3] Bompiani, G. D., Roniller, C., and Hatt, P. Y. (1959). La tissu de conduction de coeur chez le rat. Étude au microscope electronique. Arch Mal Coeur., 52 , 1257-1274

[4] Cantin, M., Gutkowska, J., Thibault, G., Milne, R. W., Ledoux, S., Chapeau, C., Garcia, P., Hamet, P., and Genest, J. (1984). Immunocytochemical localization of atrial natriuretic factor in the heart and salivary glands. Histochemistry, 80, 113-127.

[5] Cantin, M., Timm-Kennedy, M., El-Khatib, E., Huet, M., and Yunge, L. (1979). Ultrastructural cytochemistry of atrial muscle cells. Comparative study of specific granules in right and left atrium of various animal species. Anat. Rec., 193, 55-70.

[6] Chapeau, C., Gutkowska, J., Schiller, P. W., Milne, R. W., Thibault, G., Garcia, R., Genest, J., and Cantin, M. (1985). Localization of immunoreactive synthetic atrial natriuretic factor (ANF) in the heart of various animal species. J. Histochem $C y$ tochem, 33, 541-550.

[7] De Bold, A. J. (1979). Heart atria granularity effects of changes in water-electrolyte balance. Proc. Soc. Exp. Biol Med, 161, 508-511.

[8] De Bold, A. J.(1982). Tissue fractionation studies on the relationship between an atrial natriuretic factor and specific atrial granules. Can J. Physiol Pharm acol, 60, 324-330.

[9] Forssmann, W. G., Birr, C., Carlquist, M., Finke, R., Henschen, A., Hock, D., Kirchheim, H., Kreye, V., Lottspeich, F., Metz, J., Mutt, V., and Reinecke, M. (1984). The auricular myocardiocytes of the heart constitute an endocrine organ. Characterization of a porcine cardiac peptide hormone, cardiodilatin-126. Cell Tissue Res, 238, 425-430.

[10] Forssmann, W.G., Hock,D., Lottspeich,F., Henschen, A., Kreye, V., Christman, M., Reinecke, M., Metz, J., Carlquist, M., and Mutt, V. (1983). The right auricle of the heart is an endocrine organ : Cardiodilatin as a peptide hormone candidate. Anat. Embryol, 168, 307-313.

[11] Gall, J. A. M., Alcorn, D., Ferney, R., Coghlan, J. P., and Ryan, G. B. (1990). Qualitative and Quantitative analysis of granules in atrial appendage cardiocytes in different physiological states. Cell Tissue Res, 259, 529-534.

[12] Gu, J. and Gonzalez-Lavin, L. (1988). Light and electron microscopic localization of atrial natriuretic peptide in heart of spontaneously hypertensive rat. J. Histochem Cytochem, 36, 1239-1249.

[13] Jamieson, J. D. and Palade, G. E. (1964). Specific granules in atrial muscle cells. J. Cell Biol, 123, 151-172.

[14] Kangawa, K. and Matsuo, H. (1984). Purification 
and complete amino acid sequence of $\alpha$-human atrial natriuretic polypeptide ( $\alpha$-hANP). Biochem Biophys. Res. Commun, 118, 131-139.

[15] Kisch, B.(1956). Electron microscopy of the atrium of the heart. I. Guinea pig. Exp. Med Surg., 14, 99112 .

[16] Lang, R. E., Ruskoaho, H., Toht, M., Ganten, D., Unger, T., and Dietz, R. (1987). Mechanisms controlling release of atrial natriuretic peptide. In Atrial hormones and other natriuretic factors, pp 19-32, Mulrow, P. J. and Schrier, R. (eds.), Waverly Press, Baltimore.

[17] Manning, P. T., Schwartz, D., Katsube, N. C., Holmberg, S. W., and Needleman, P.(1985). Vasopressin-stimulated release of atriopeptin : endocrine antagonist in fluid homeostasis. Science, 229, 395397.

[18] Mckenzie, J. C., Tanaka, I., Misono, K. S., and Inagami, T. (1985). Immunocytochemical localization of atrial natriuretic factor in the kidney, adrenal medulla, pituitary, and atrium of rat. J. Histochem Cytochem, 33, 828-832.

[19] Metz, J., Mutt, V., and Forssmann, W. G. (1984). Immunohistochemical localization of cardiodilatin in myoendocrine cells of the cardiac atria. Anat. Embryol, 170, 123-127.

[20] Netchitailo, P., Feuilloley, M., Pelletier, G., Cantin, M., De Lean, A., Leboulenger, F., and Vaudry, H. (1986). Localization and characterization of atrial natriuretic factor (ANF)-like peptide in the frog atrium. Peptides, 7, 573-579.

[21] Palade, G. E. (1961). Secretory granules in the atrial myocardium. Anat. Rec., 139, 262.

[22] Rapp, J. P. (1987). Atrial natriuretic factor in animal models for hypertension. In Atrial hormones and other natriuretic factors, pp 111-116, Mulrow, P. J. and Schrier, R. (eds.), Waverly Press, Baltimore.

[23] Saper, C. B., Standaert, D. G., Currie, M. G., Schwartz, D, Geller, D. M., and Needleman, P.(1985). Atriopeptin-immunoreactive neurons in the brain : Presence in cardiovascular regulatory areas. Science. 227, 1047-1049.

[24] Skepper, J. N. and Navaratnam, V. (1988). Analysis of the apparent heterogeneity of specific hearts ganules in rat atrial myocytes ; an ultrastructural study including immunocytochemistry. Histochem J., 20, 1-10.

[25] Tomisawa, M. (1969). Atrial specific granules in various mammals. Arch Histol Jap., 30, 449-465.

[26] Toshimori, H., Nakazato, M., Toshimori, K., Asai, J., Matsukura, S., Oura, C., and Matsuo, H. (1988). Distribution of atrial natriuretic polypeptide (ANP)containing cells in the rat heart and pulmonary vein. Cell Tissue Res., 251, 541-546.

[27] Yunge, L., Ballak, M., Beuzeron, J., and Cantin, M. (1980). Ultrastructural cytochemistry of atrial and ventricular cardiocytes of the bullfrog(Rana Catesbeiana). Relationship of specific granules with renin-like activity of the myocardium. Can. J. Phy siol Pharmacol, 58, 1463-1471.

\section{マウス，ラットおよびスナネズミの心房筋細胞に拈ける心房性 ナトリウム利尿ペプチド (ANP) 顆粒の微細構造について}

御船弘治·鈴木秀作* ·野田安孝・毛利資郎**·望月公子***

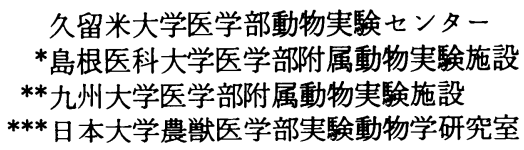

マウス，ラット及びスナネズミの心房ならびに心室筋 細胞を免疫組織化学的に, 右側の心房及び心耳筇細胞を 透過電子顕微鏡で観察し，さらにこれら細胞の ANP 顆 粒を形態計測により解析した。免疫組織化学的には 3 種 の動物種共に，心房に ANP 陽性細胞がみられ，なかで も右側の心耳が最も強く反応した。これらの反応はスナ ネズミよりマウス・ラットの方が，より顕著であった。 一方，心室筋にはいずれの動物種共に，ANP 陽性細胞 は認められなかったが，時に心室中隔の心内膜下に陽性 細胞が存在した。電顕的には 3 動物種の心房筇ならびに 心耳筋細胞は種々の大きさの ANP 顆粒を有し，その数 も様々で，それらの顆粒は扔もに核周囲のゴルジ野にみ られ，䇗原線維間にも少数存在した。これらの顆粒は 2
種類に分類でき，A顆粒は限界膜を有する電子密度の高 い均質無構造の顆粒で，B顆粒は限界膜が不明瞭でA顆 粒に比べ電子密度が低い微細線維粒状の顆粒であった。 形態計測的に右側の心耳筋ならびに心房筋細胞のA，B 顆粒の数扣よび両顆粒の数は, スナネズミに比べマウ ス,ラットが有意に多かった。3 動物種において, 両顆 粒の数は心房筋よりも心耳筋細胞に有意に多かったが,

$\mathrm{A}$ 顆粒と B 顆粒の数においては有意差はみられなかっ た。 A， B 顆粒の大きさは，心耳筋，心房筋細胞共にス ナネズミに比べマウス，ラットが有意に大きく，また， $\mathrm{A}$ 顆粒が $\mathrm{B}$ 顆粒に比へ，いずれの動物種共に有意に大き かった。 


\section{Explanation of Figures}

Figs. 1-9 represent immunohistochemica staining of ANP in myocardiocytes. All magnifications, with the exception of Fig. 7 are $\times 314$ (original magnification).

Fig. 1. Right atrium of the rat. Reaction deposits for ANP are demonstrated in the perinuclear regions (arrowheads) of the cardiocytes.

Fig. 2. Left atrium of the rat. Reactivity is less than in right atrial cardiocytes.

Fig. 3. Right auricle of the rat. The most intense reaction is seen in this region.

Fig. 4. Left auricle of the rat. The reactions are weaker than right auricular cardiocytes.

Fig. 5. Right auricle of the mouse. The reactions are strong, similar to those in the rat.

Fig.6. Right auricle of the Mongolian gerbil. Note that the reactions are less than in the mouse or rat.

Fig. 7. Right atrium of the rat. Subpericardial cardiocytes are more reactive than those located in the deep atrial wall. Original magnification $\times 157$

Figs. 8, 9. Ventricular septum of the Mongolian gerbil. ANP immunoreactivity is not detected in the ventricular wall, but is occasionally seen in the subendocardium of the ventricular septum (Fig. 9, arrowheads).

Fig. 10-16. Transmission electron micrographs of cardiocytes.

Fig. 10. Right auricular cardiocyte of the mouse. Many ANP granules are packed at the pole of nucleus. Some granules are observed throug- hout the sarcoplasmic layers intervening between myofibrilar bundles.

Fig. 11. Right auricular cardiocyte of the rat. ANP granules of various size are located near the Golgi apparatus in the paranuclear region, and most of the granules are located at the poles of the elongated nucleus.

Fig. 12. Right auricular cardiocyte of the Mongolian gerbil. There are fewer granules in the cardiocytes of the Mongolian gerbil than in those of the mouse or rat.

Fig. 13. Cardiocyte of the right atrium exclusive of the auricle, of the mouse. There are fewer granules in right atrial cardiocytes than in right auricular cardiocytes.

Fig. 14. High magnification of right auricular cardiocyte of the mouse. Two types of granules are found. The A-granule (A) contains a conspicuous electron dense-core separated from the limiting membrane by a narrow electron-lucent halo, and the B-granulee (B) exhibits a profile with a fibrillogranular, less electron-dense core than in the case of the A-granule.

Fig. 15. High magnification of the Golgi area in the perinuclear region of a right auricular cardiocyte of the Mongolian gerbil. The Golgi apparatus is less developed in the Mongolian gerbil than in the mouse or rat.

Fig. 16. High magnification of secretory granules in Fig. 15. Two types of granules are seen. A : type A granule B : type B granule 

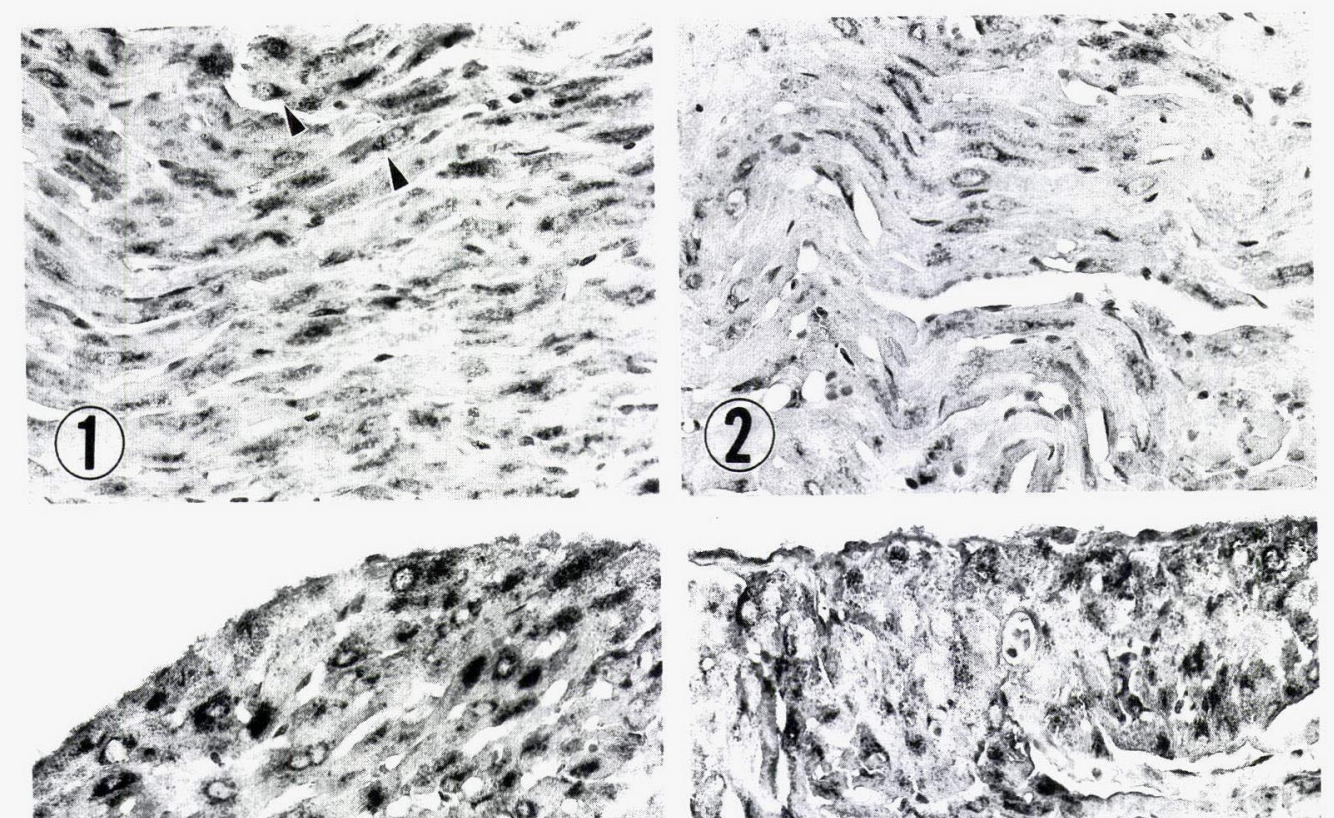

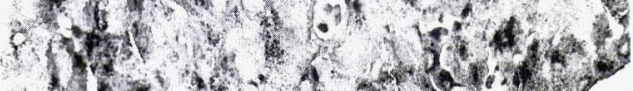

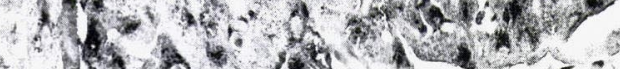

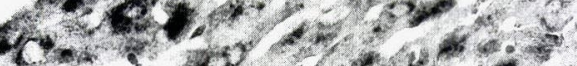

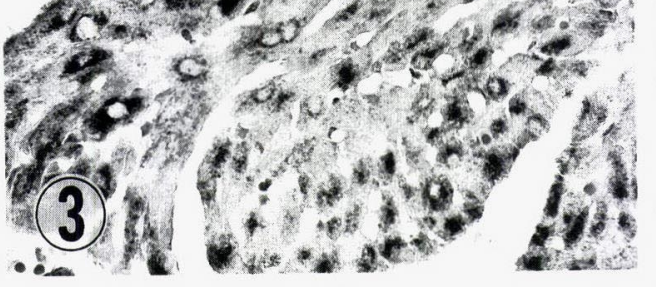

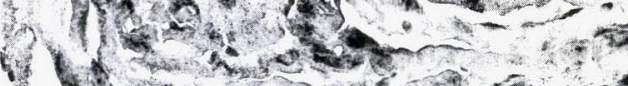

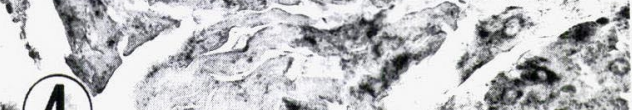

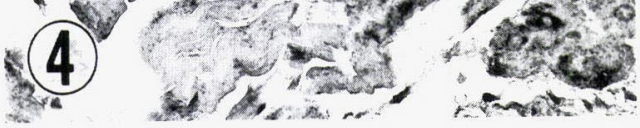
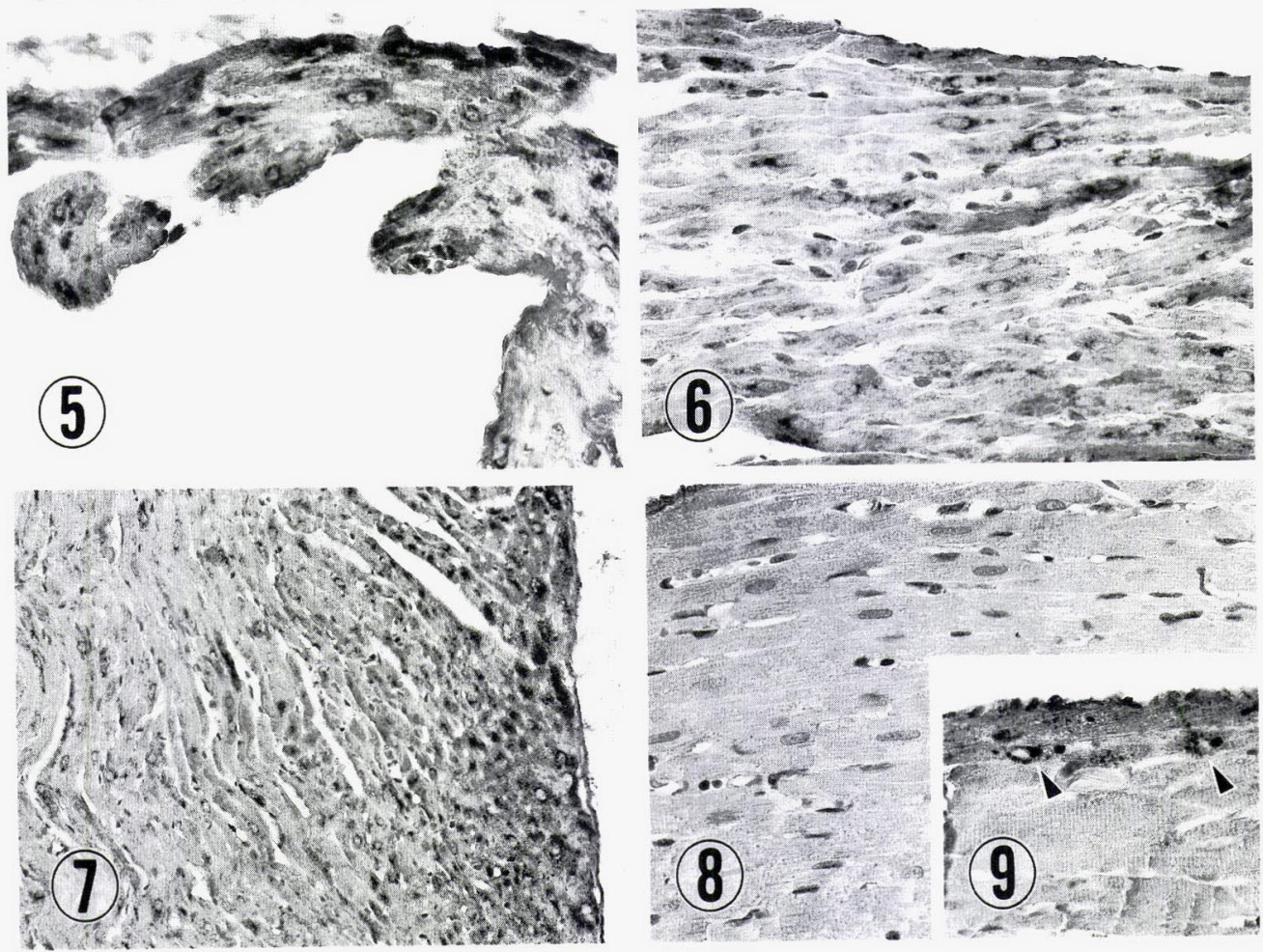


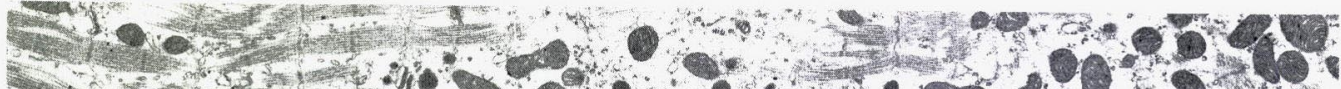

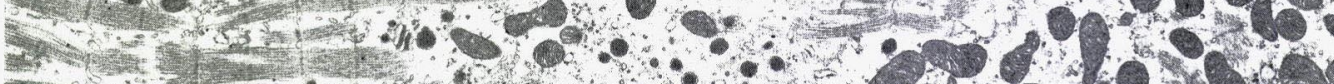

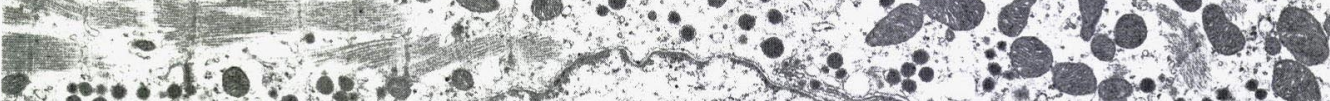

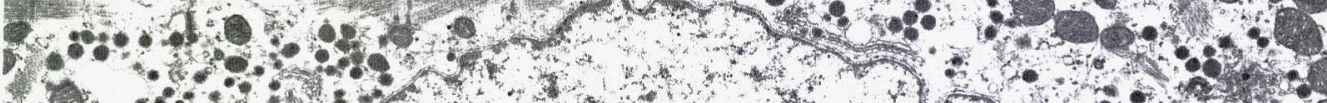

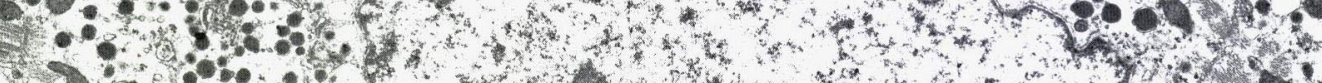

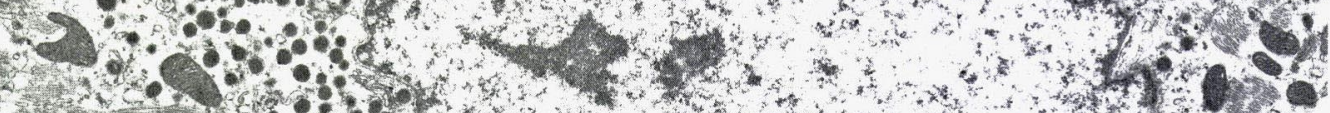

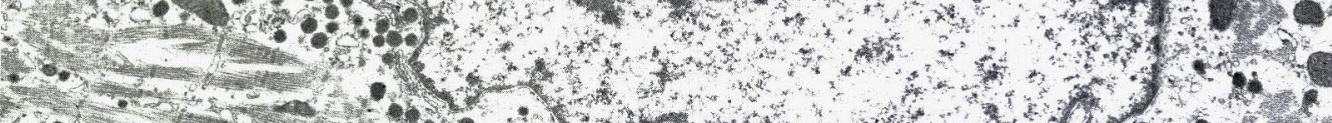

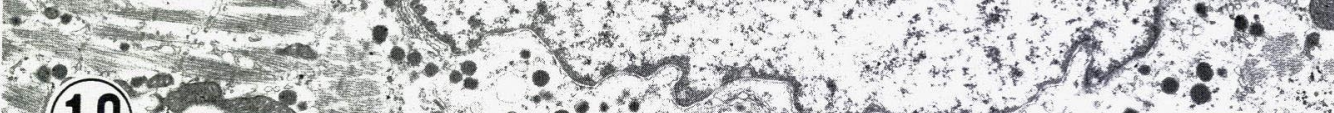

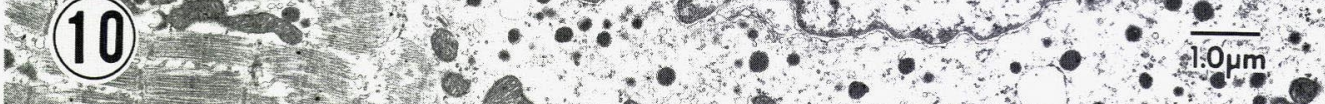

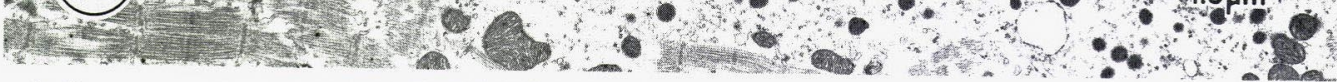

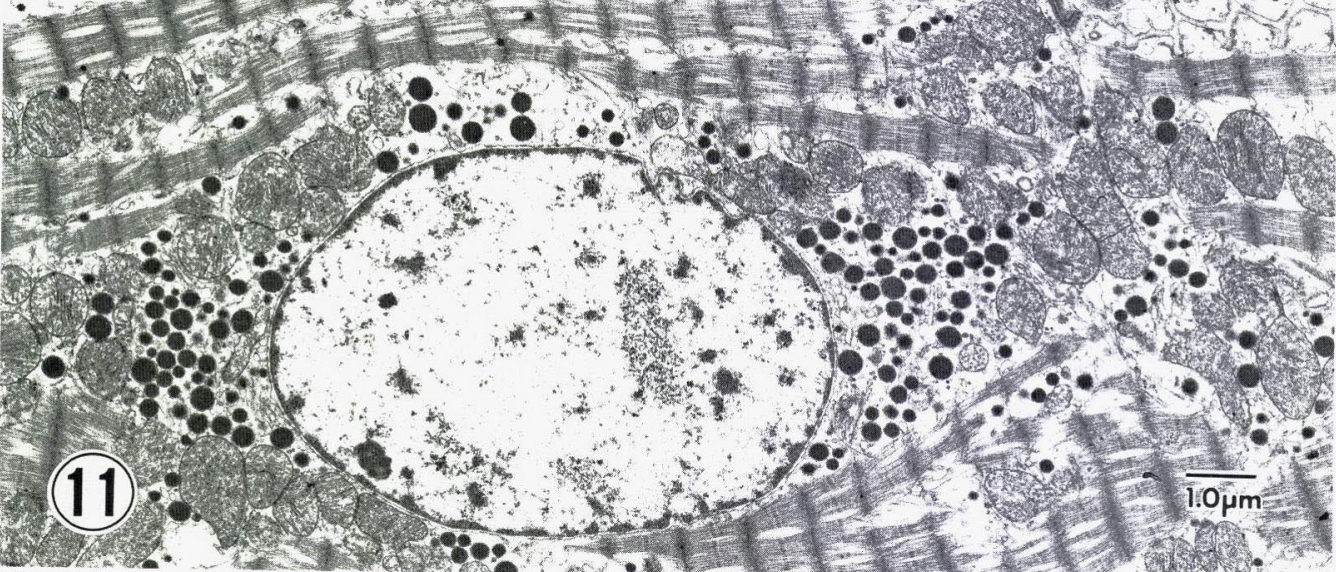
30

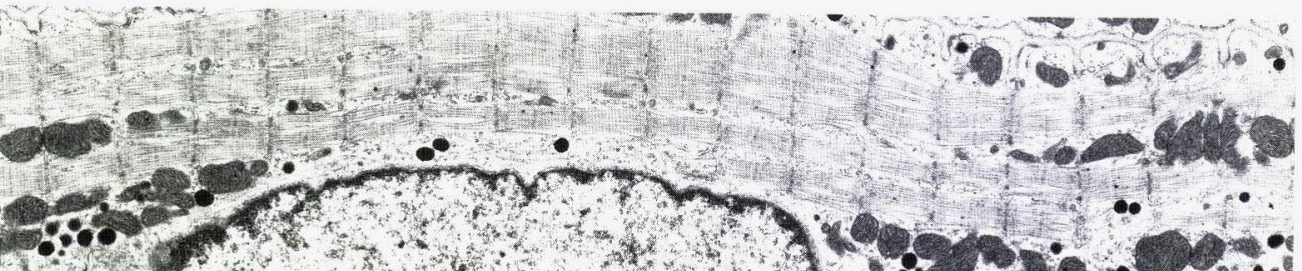

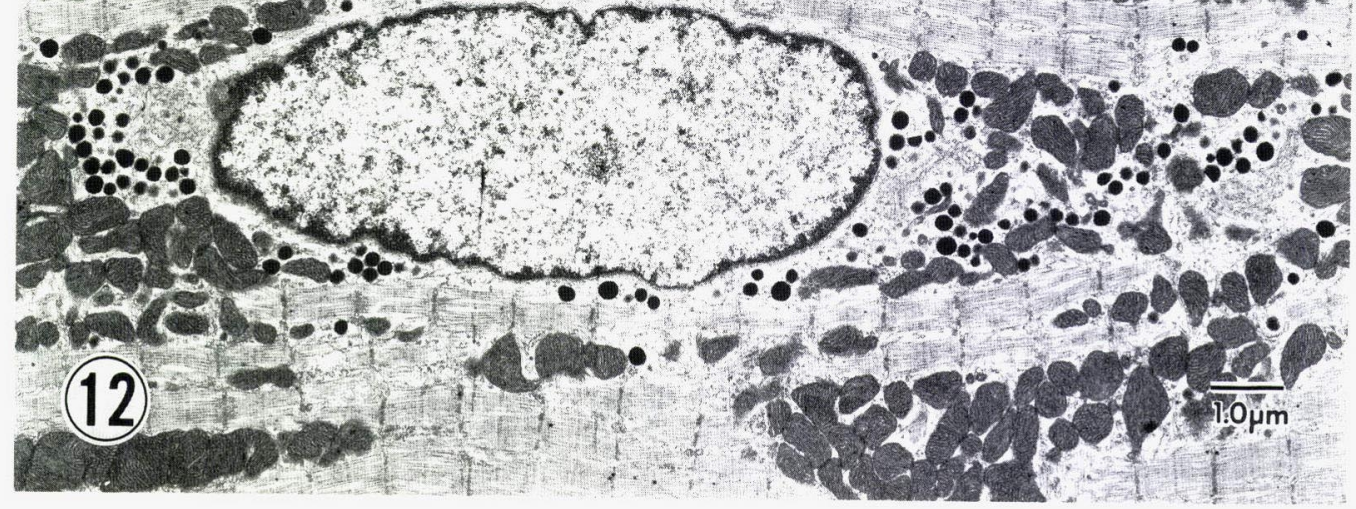




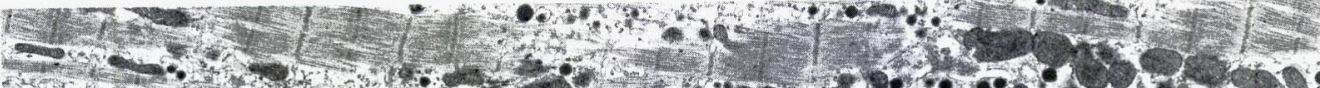

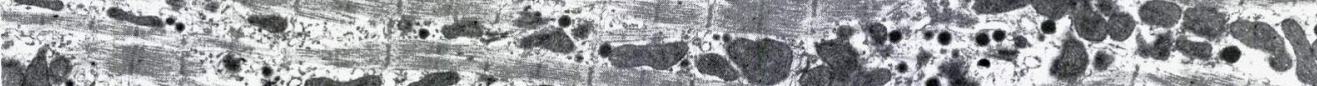

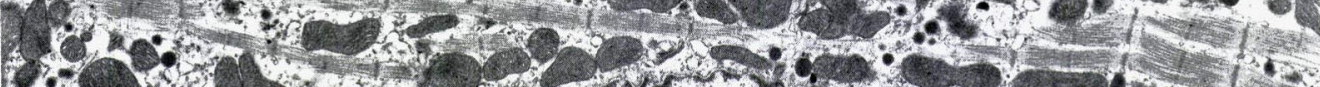
-D. D.

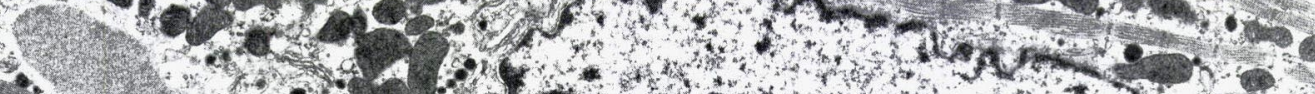

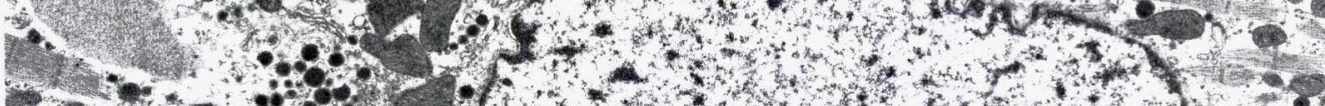

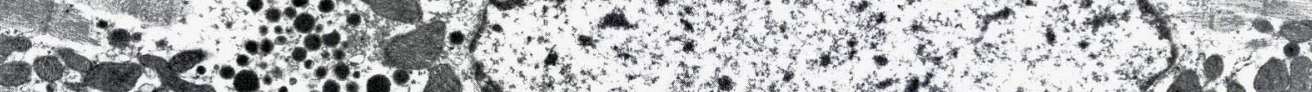

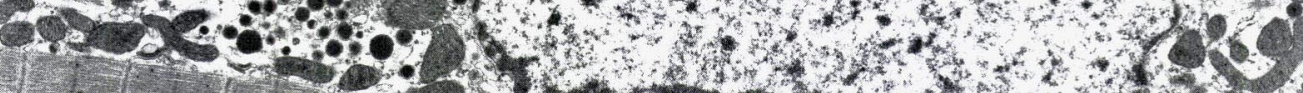

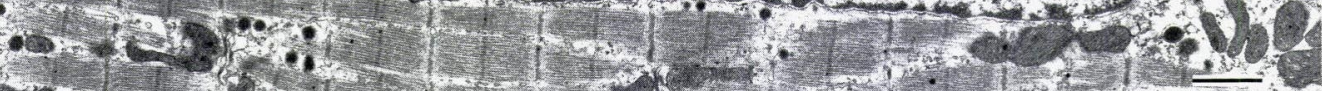

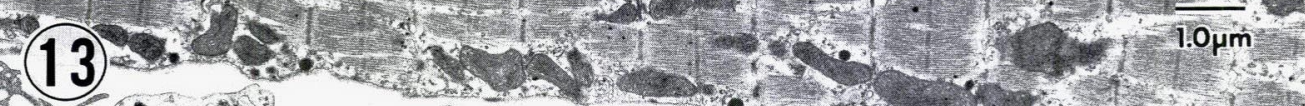

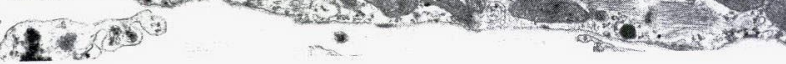

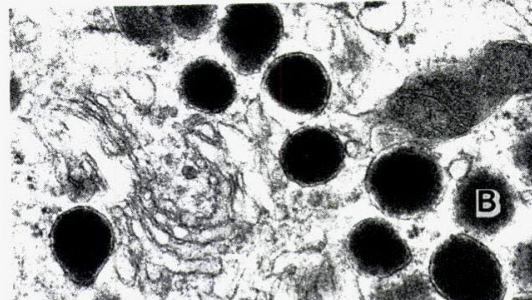

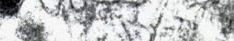

1. 010

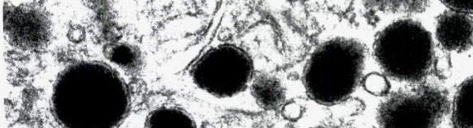

(2)

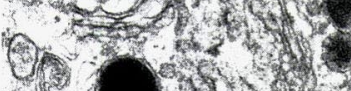

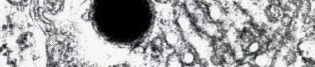

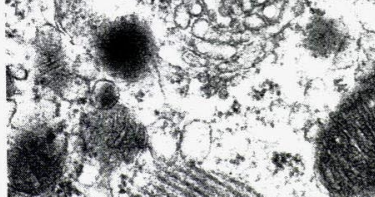
-

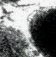

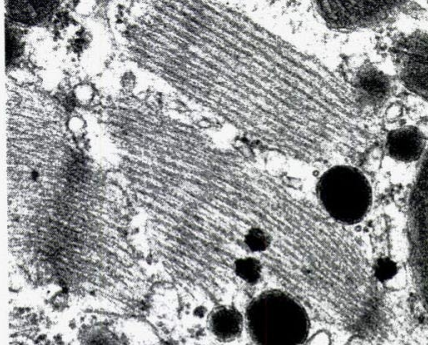

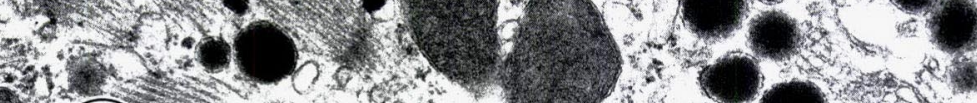

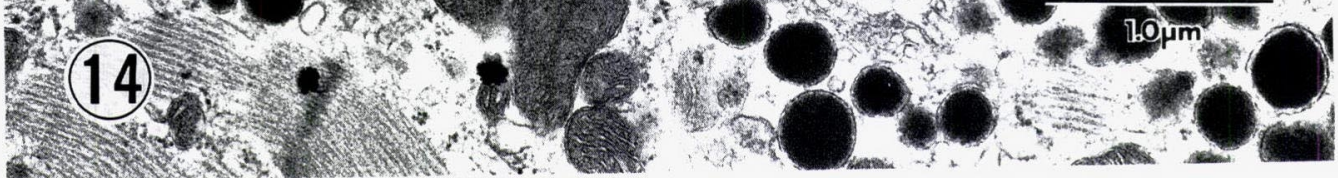

A

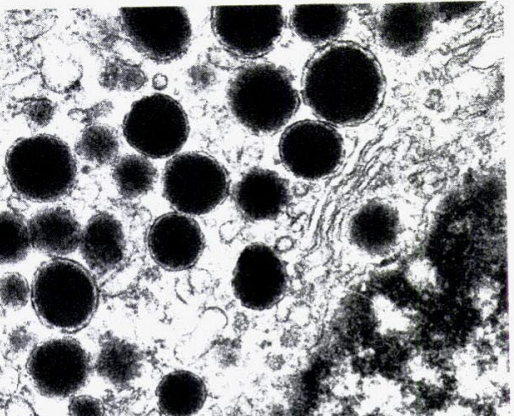

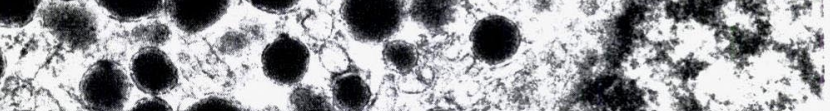

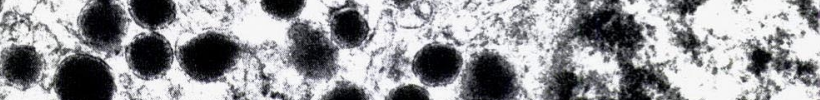
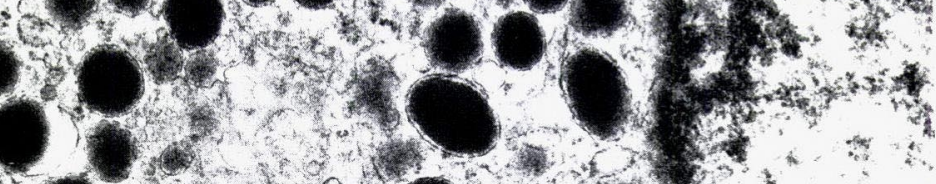

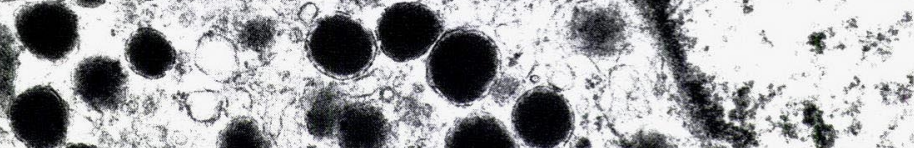

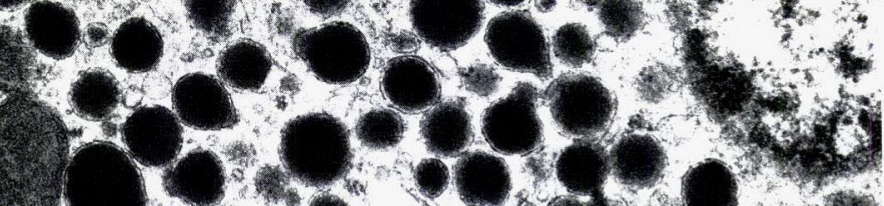




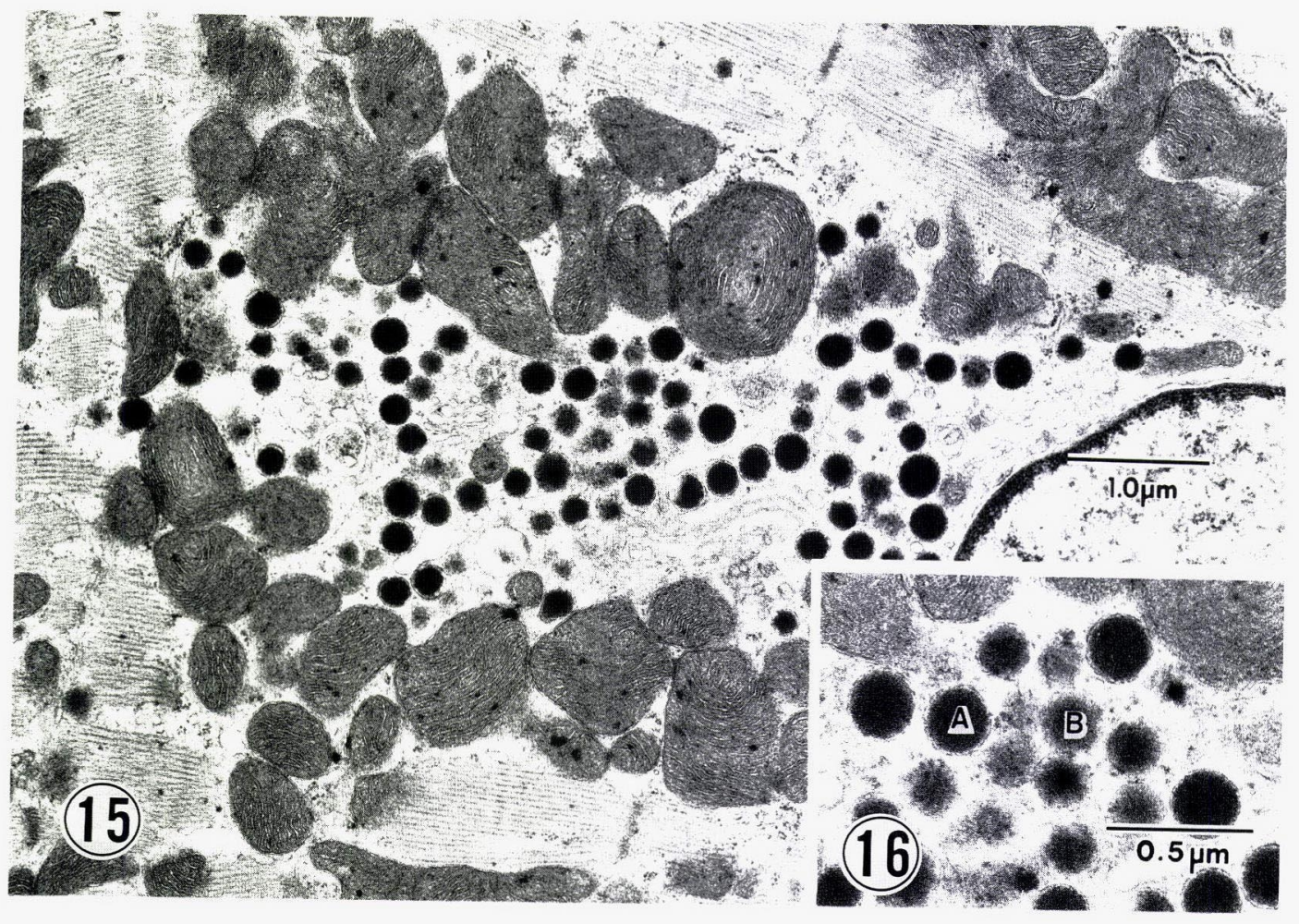

